OPEN ACCESS

Edited by:

Mathias Toft,

University of Oslo, Norway

Reviewed by:

Noriko Miyake,

Yokohama City University, Japan Yanick Crow,

INSERM U1163 Institut Imagine, France

Gillian Inara Rice,

The University of Manchester, United Kingdom

*Correspondence:

Xiaotun Ren rxtsjk@126.com

Specialty section:

This article was submitted to Neurogenetics,

a section of the journal

Frontiers in Neurology

Received: 21 July 2020

Accepted: 11 May 2021

Published: 17 June 2021

Citation:

Jin H, Ren X, Wu H, Hou Y and Fang F (2021) Case Report: Clinical Features

of Childhood Leukoencephalopathy With Cerebral Calcifications and Cysts Due to SNORD118 Variants. Front. Neurol. 12:585606. doi: 10.3389/fneur.2021.585606

\section{Case Report: Clinical Features of Childhood Leukoencephalopathy With Cerebral Calcifications and Cysts Due to SNORD118 Variants}

\author{
Hong Jin ${ }^{1}$, Xiaotun Ren ${ }^{1 *}$, Husheng $\mathrm{Wu}^{1}$, Yanqi Hou ${ }^{2}$ and Fang Fang ${ }^{1}$ \\ ${ }^{1}$ Department of Neurology, Beijing Children's Hospital, Capital Medical University, National Center for Children's Health, \\ Beijing, China, ${ }^{2}$ Running Gene Inc., Beijing, China
}

Background: Leukoencephalopathy with cerebral calcifications and cysts (LCC) is a rare autosomal recessive cerebral microangiopathy. Recently, biallelic variants in a non-protein-coding gene SNORD118 have been discovered to cause LCC.

Case Presentation: We here report a genetically confirmed childhood case of LCC. The patient was a 4-year-and-1-month-old boy with focal seizures. The age at onset of his seizure was 10 days after birth. The seizures were well-controlled by antiepileptic treatment but reoccurred twice due to a head impact accident and a fever, respectively. He suffered from a self-limited esotropia and unsteady running gait during the seizure onset. He had the typical neuroimaging triad of multifocal intracranial calcifications, cysts, and leukoencephalopathy. Genetic analysis indicated that he carried compound heterozygous variants of $\mathrm{n} .{ }^{*} \mathrm{C} \mathrm{C}>\mathrm{T}$ and $\mathrm{n} .3 \mathrm{C}>\mathrm{T}$ in SNORD118, which were inherited from his parents.

Conclusion: We report a childhood LCC case with compound heterozygous variants in SNORD118. To the best of our knowledge, the patient reported in our case had the youngest onset age of LCC with a determined genotype. The triad cerebral-imaging findings of calcifications, cysts, and leukoencephalopathy provide a crucial diagnostic basis. Moreover, the gene assessment, together with the clinical investigations, should be considered for the diagnosis of LCC.

Keywords: leukoencephalopathy, calcifications, cysts, SNORD118, child

\section{INTRODUCTION}

Leukoencephalopathy with cerebral calcifications and cysts (LCC), first reported by Labrune in 1996, is a rare neurological microangiopathy characterized by leukoencephalopathy, intracranial calcifications, and cysts identified in cerebral imaging (1). About 100 cases have been reported so far (2-6). Leukoencephalopathy with cerebral calcifications and cysts has various clinical presentations, including seizures, cognitive decline, pyramidal/extrapyramidal signs, ataxia, and symptoms and signs consequent to increased intracranial pressure with the expanding cystic lesions (1, 7-10). Biallelic variants in gene SNORD118 have been recently identified to be the cause of LCC (11). 
SNORD118 is a non-protein-coding gene producing a special type of small nucleolar RNA (snoRNA), the box C/D snoRNA $\mathrm{U}$, which is involved in the modification and processing of rRNAs and the construction of ribosomes. It was investigated that disease-causing variations of SNORD118 would affect the activity of U8, while the further pathological mechanism of the disease was still unclear (12). We here present a clinically and genetically confirmed childhood case of LCC in order to consolidate the understanding of clinical features and diagnostic bases of the disease.

\section{CASE PRESENTATION}

A 4-year-and-1-month-old boy was referred to us for intermittent focal seizures. The first onset of his seizure was at 10

Abbreviations: LCC, leukoencephalopathy with cerebral calcifications and cysts; MRI, magnetic resonance imaging; CT, computed tomography; FLAIR, fluidattenuated inversion recovery; snoRNA, small nucleolar RNA.

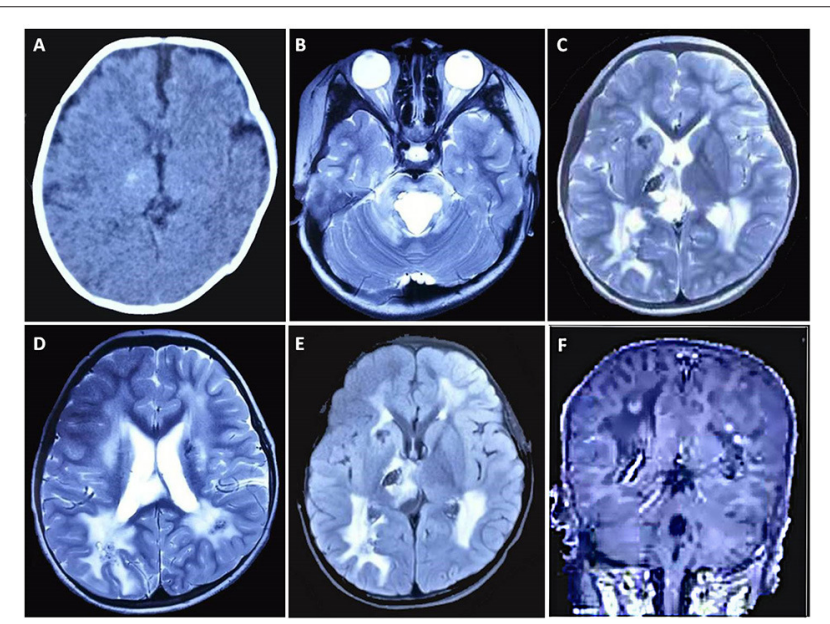

FIGURE 1 | Brain CT and MRI findings of the case. (A) CT scan taken at 1 month after birth shows a focal calcification in the right thalamus. MRI [(B-D) T2WI, (E) FLAIR, (F) contrast-enhanced sequence] taken at 4 years and 1 month of age demonstrates bilateral calcifications and cysts, some with contrast enhancement, in the periventricular regions, basal ganglia, right thalamus, and pons, along with increased T2/FLAIR signal changes in periventricular white matter. days after birth, and his initial brain CT taken at 1 month of age showed a focal calcification in the right thalamus (Figure 1A). The seizures had been well-controlled by levetiracetam treatment (15 mg/kg/day, divided Q12h as an initial dose and increased gradually to $25 \mathrm{mg} / \mathrm{kg} /$ day, divided Q12h) for nearly 4 years but frequently recurred a week ago after he fell from a slide and had his head bump against the ground. He was born from unrelated parents after an uneventful pregnancy and developed normally. He could talk and walk independently at the age of 1 year. When he was 3 years old, he received the Gesell Institute's developmental examination with the DQ score of 92. No abnormality was found on general physical, ophthalmological, neurological, or biochemical blood examinations.

Magnetic resonance imaging demonstrated bilateral calcifications and cysts in the periventricular regions, basal ganglia, right thalamus, and pons. Some areas also had contrast enhancement. Increased T2/FLAIR (fluid-attenuated inversion recovery) signal was also identified in periventricular white matter (Figures 1B-F). According to the results described above, the patient was clinically diagnosed with LCC.

Whole-exome sequencing (WES) and Sanger sequencing were performed by MyGenostics (Beijing, China) using their standard process, which is available in the previous report (13). Compound heterozygous n. ${ }^{*} 9 \mathrm{C}>\mathrm{T}$ and $\mathrm{n} .3 \mathrm{C}>\mathrm{T}$ in SNORD 118 (NR_033294) of the patient were detected by genetic testing. Both two variants were inherited from his parents and had already been reported to cause disease (PP5) $(11,12) . n .{ }^{*} 9 \mathrm{C}>\mathrm{T}$ is a paternal mutation in the region immediately downstream of SNORD118, while n.3C $>\mathrm{T}$ is a single-nucleotide substitution at the $5^{\prime}$ end of SNORD118 inherited from his mother. They all have low allele frequencies in the genome databases of healthy controls [including 1,000 Genomes, ExAC, and gnomAD (PM2)] and could disturb the processing of SNORD118 transcript (PVS1) (11, 14). Therefore, these two variants considered a likely pathogenic variant according to the standard of ACMG (15).

The boy continued to receive oral antiepileptic treatment with levetiracetam (250 mg in the morning and $375 \mathrm{mg}$ at night, Q12h, about $28 \mathrm{mg} / \mathrm{kg} /$ day) (Figure 2). In the following 2 years and 3 months, he suffered from a self-limited esotropia and unsteady running gait for 5 months, and his seizures were controlled after another 2 months. He was free from seizure for 8 months until he had a fever of $40^{\circ} \mathrm{C}$ at the age of 5 years and 4 months. His febrile seizures lasted for a few minutes and stopped without additional treatment, and no recurrence was noticed. The repeat cranial

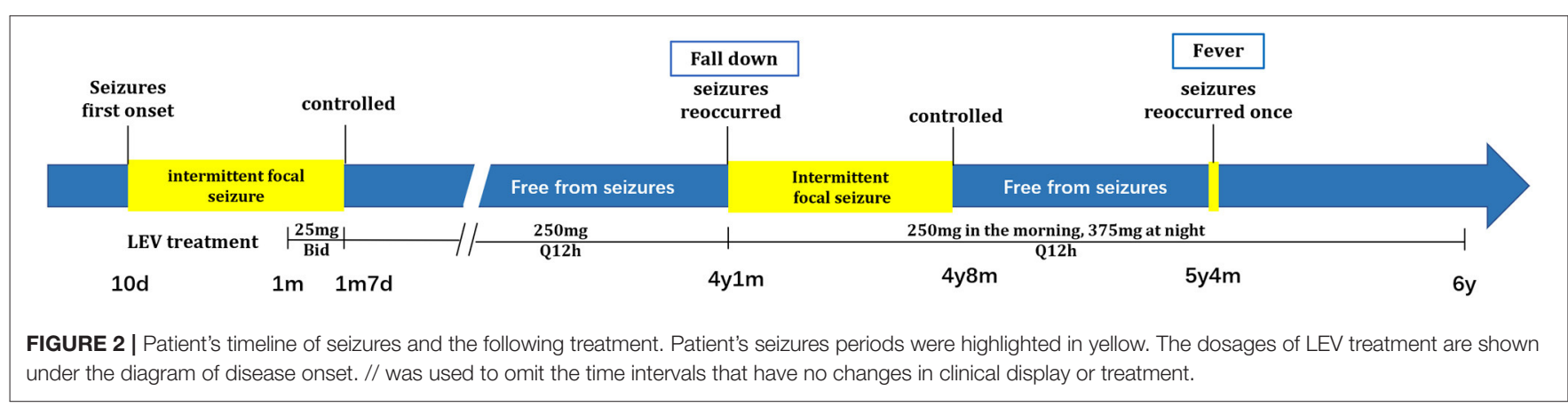


TABLE 1 | SNORD118 variants identified in patients with LCC.

\begin{tabular}{|c|c|c|c|c|c|}
\hline Variant $^{b}$ & $\begin{array}{l}\text { Genomic } \\
\text { coordinates }^{a}\end{array}$ & $\begin{array}{c}\text { gnomAD total allele } \\
\text { count }\end{array}$ & Hom & Het & $\begin{array}{c}\text { Calculated gnomAD } \\
\text { frequency }\end{array}$ \\
\hline n. $-70_{-}^{*} 76 \mathrm{del}$ & g.8076696_8076977del & & & & Novel \\
\hline n.-54_-49del & g.8076955_8076960del & 224,458 & 0 & 0 & Novel \\
\hline n.-7_22dup & g.8076885_8076913dup & 231,956 & 0 & 0 & Novel \\
\hline n. $-6 G>A$ & g.8076912C>T & 262,340 & 0 & 224 & 0.0008539 \\
\hline n. $2 \mathrm{~T}>\mathrm{C}$ & g.8076905A>G & 230,692 & 0 & 5 & 0.00002167 \\
\hline n. $3 \mathrm{C}>\mathrm{A}$ & g.8076904G >T & 231,102 & 0 & 1 & 0.000004327 \\
\hline n. $3 \mathrm{C}>\mathrm{T}$ & g.8076904G $>A$ & 262,476 & 2 & 389 & 0.001482 \\
\hline n. $5 \mathrm{~T}>\mathrm{C}$ & g.8076902A>G & 231,322 & 0 & 11 & 0.0000475528 \\
\hline n. $8 \mathrm{G}>\mathrm{A}$ & g.8076899C>T & 262,710 & 4 & 724 & 0.002756 \\
\hline n. $8 \mathrm{G}>\mathrm{C}$ & g.8076899C>G & 262,710 & 0 & 4 & 0.00001523 \\
\hline n. $19 \mathrm{C}>\mathrm{G}$ & g. $8076888 \mathrm{G}>\mathrm{C}$ & 263,190 & 0 & 9 & 0.00003420 \\
\hline$n .20 C>T$ & g. $8076887 G>A$ & 231,710 & 0 & 7 & 0.00003021 \\
\hline n. $24 \mathrm{C}>\mathrm{A}$ & g.8076883G > T & 231,996 & 0 & 2 & 0.000008622 \\
\hline n. $24 \mathrm{C}>\mathrm{T}$ & g.8076883G $>A$ & 263,352 & 0 & 84 & 0.0003190 \\
\hline n. $39 \mathrm{G}>\mathrm{T}$ & g.8076868C >A & 232,004 & 0 & 2 & 0.000008621 \\
\hline n. $39 G>C$ & g. $8076868 C>G$ & 263,390 & 0 & 33 & 0.0001253 \\
\hline n.39_40insT & g.8076867_8076868insA & 231,998 & 1 & 25 & 0.000108 \\
\hline n. $42 \mathrm{G}>\mathrm{A}$ & g.8076865C>T & 263,436 & 0 & 282 & 0.001070 \\
\hline n.56dup & g.8076851dup & 232,100 & 0 & 2 & 0.000008617 \\
\hline n. $57 \mathrm{G}>\mathrm{T}$ & g.8076850C >A & 263,492 & 0 & 0 & Novel \\
\hline n. $57 \mathrm{G}>\mathrm{A}$ & g.8076850C>T & 263,492 & 0 & 7 & 0.00002657 \\
\hline n.58dup & g.8076849dup & 263,490 & 0 & 0 & Novel \\
\hline n. $58 \mathrm{~A}>\mathrm{G}$ & g.8076849T>C & 263,490 & 0 & 6 & 0.00002277 \\
\hline n.59T > G & g.8076848A>C & 263,468 & 0 & 0 & Novel \\
\hline n. $60 \mathrm{G}>\mathrm{C}$ & g. $8076847 C>G$ & 232,080 & 0 & 0 & Novel \\
\hline n.60_61insT & g.8076846_8076847insA & 263,474 & 0 & 2 & 0.000007591 \\
\hline n. $61 \mathrm{~A}>\mathrm{G}$ & g.8076846T>C & 263,474 & 0 & 16 & 0.00006073 \\
\hline n. $61 \mathrm{~A}>\mathrm{T}$ & g.8076846T>A & 232,094 & 0 & 2 & 0.000008617 \\
\hline n. $64 \mathrm{G}>\mathrm{A}$ & g.8076843C>T & 263,458 & 0 & 35 & 0.0001328 \\
\hline n. $72 A>G$ & g.8076835 T>C & 232,094 & 0 & 16 & 0.00006894 \\
\hline n.73T>G & g.8076834A>C & 232,092 & 0 & 0 & Novel \\
\hline n. $74 G>A$ & g.8076833C>T & 263,478 & 0 & 16 & 0.00006073 \\
\hline n.74G $>T$ & g. $8076833 \mathrm{C}>\mathrm{A}$ & 263,478 & 0 & 0 & Novel \\
\hline n. $75 A>G$ & g.8076832T>C & 232,094 & 0 & 4 & 0.00001723 \\
\hline n. $75 A>C$ & g.8076832T>G & 31,392 & 0 & 1 & 0.00003186 \\
\hline n. $81 G>A$ & g.8076826C>T & 232,082 & 0 & 11 & 0.00004740 \\
\hline n. $81 G>C$ & g.8076826C>G & 232,082 & 0 & 0 & Novel \\
\hline n. $82 A>G$ & g.8076825T>C & 263,450 & 0 & 18 & 0.00006832 \\
\hline n.92C>T & g.8076794G $>A$ & 263,358 & 0 & 11 & 0.00004177 \\
\hline n. $100 T>G$ & g.8076807A>C & 232,038 & 0 & 0 & Novel \\
\hline n.103G $>A$ & g.8076804C>T & 232,002 & 0 & 4 & 0.00001724 \\
\hline n.104G>A & g.8076803C>T & 263,390 & 0 & 110 & 0.0004176 \\
\hline n.113C>T & g.8076794G >A & 263,358 & 0 & 11 & 0.00004177 \\
\hline n. $117 \mathrm{C}>\mathrm{G}$ & g. $8076790 G>C$ & 263,344 & 0 & 17 & 0.0000646 \\
\hline n. $118 \mathrm{~T}>\mathrm{G}$ & g.8076789A >C & 231,904 & 0 & 1 & 0.000004312 \\
\hline n.119G $>T$ & g.8076788C >A & 263,272 & 0 & 0 & Novel \\
\hline n.126C>T & g.8076781G $>A$ & 263,122 & 0 & 31 & 0.0001178 \\
\hline n.127C>G & g. $8076780 G>C$ & 231,700 & 0 & 10 & 0.00004316 \\
\hline n.130T>C & g.8076777A>G & 231,804 & 0 & 2 & 0.000008628 \\
\hline n. $131 \mathrm{C}>\mathrm{A}$ & g.8076776G>T & 263,148 & 0 & 0 & Novel \\
\hline
\end{tabular}


TABLE 1 | Continued

\begin{tabular}{|c|c|c|c|c|c|}
\hline Variant $^{\mathrm{b}}$ & $\begin{array}{l}\text { Genomic } \\
\text { coordinates }^{a}\end{array}$ & $\begin{array}{c}\text { gnomAD total allele } \\
\text { count }\end{array}$ & Hom & Het & $\begin{array}{c}\text { Calculated gnomAD } \\
\text { frequency }\end{array}$ \\
\hline $\mathrm{n} .131 \mathrm{C}>\mathrm{G}$ & g.8076776G >C & 263,148 & 0 & 4 & 0.00001520 \\
\hline $\mathrm{n} .131 \mathrm{C}>\mathrm{T}$ & g.8076776G >A & 263,148 & 0 & 32 & 0.0 .000122 \\
\hline$n \cdot{ }^{*} 1 C>T$ & g.8076770G >A & rs117595965 & 5 & 1328 & 0.005054 \\
\hline n. ${ }^{\star} 5 \mathrm{C}>\mathrm{G}$ & g.8076766G >C & 262,552 & 0 & 159 & 0.0006056 \\
\hline n. ${ }^{*} 9 \mathrm{C}>\mathrm{T}$ & g.8076762G $>A$ & 262,616 & 2 & 505 & 0.001923 \\
\hline n. ${ }^{*} 10 \mathrm{G}>\mathrm{T}$ & g.8076761C >A & 262,502 & 4 & 655 & 0.002495 \\
\hline n. ${ }^{*} 10 G>A$ & g.8076761C > T & 262,502 & 0 & 30 & 0.000114 \\
\hline
\end{tabular}

gnomAD, genome aggregation database; Hom, homozygous; Het, heterozygous.

The asterisk denotes that the nucleotide in question is located in the 3' extension of human pre-U8.

${ }^{a}$ All genomic coordinates should be preceded by Chr17(GRCh37).

bSNORD118 NR 033294.1.

MRI did not show any notable changes. Moreover, he could run and jump freely, and learn things quickly in the kindergarten, as informed in a recent telephone follow-up.

\section{DISCUSSION}

Leukoencephalopathy with cerebral calcifications and cysts is a rare progressive chronic cerebral microangiopathy with various clinical presentations. So far, the clinical diagnosis of LCC was mainly counting on the neuroimaging screening. Characteristic neuroimaging features of LCC include asymmetric calcifications, diffuse leukoencephalopathy, multiple cysts of different sizes with contrast enhancement in the wall, and unusual bleeding in parenchyma or cysts $(8-10,16)$. Calcifications are reported predominantly in the basal ganglia, thalami, brainstem, dentate nuclei, and white matter, but may also be detected in the cerebral and cerebellar cortex $(16,17)$. With sparing of $U$ fibers, corpus callosum, and gray matter, asymmetrical or relatively symmetrical leukoencephalopathy is usually distributed in periventricular and deep white matter, but relatively rare in the subcortical white matter. Multiple cysts can be observed over the entire brain parenchyma, especially appearing in a high frequency of the supratentorial region $(2,17)$. Susceptibility-weighted imaging of patients often exhibits microbleedings and micro-calcifications, which implies that LCC might be associated with the abnormalities of micro-vessels. Histopathological staining of biopsies from LCC patients can also be used for diagnosis. Angiomatous-like rearrangement of micro-vessels can always be identified as the primary prominent pathological feature, together with perivascular foci of dystrophic calcifications and hemosiderin deposits, hyaline degeneration, gliosis, and formation of Rosenthal fibers $(1,2,8$, 9). However, LCC was easy to be misdiagnosed as cerebroretinal microangiopathy with calcifications and cysts, which is also called Coats plus syndrome and appears similar neuroimaging displays and histopathological features, caused by variants of the CTC1 gene (18). Our patient had the typical cerebral-imaging features of LCC, and the diagnosis was finally confirmed by genetic analysis. Since his initial CT scan taken at 1 month after birth revealed a focal calcification lesion in the right thalamus, we suspect that the disease might occur in the fetus and have already developed for a while.

SNORD118 on chromosome 17p13.1 encodes the box C/D snoRNA U8, which is an evolutionarily conserved RNA involved in the biogenesis and function of ribosome (19). The snoRNA U8 consists of a conserved box C/D motif and LSm (like-Sm) binding site, which are important for the binding of four proteins (15.5K, NOP56, NOP58, and fibrillarin) and the formation of a ribonucleoprotein complex, respectively $(20,21)$. Variants in these two regions would result in reduced binding to the $15.5 \mathrm{~K}$ protein and decrease the stability of the structure of the ribonucleoprotein complex in comparison to wild-type sequence (11), acting as functional null alleles. Otherwise, it has also been found that variants in the $5^{\prime}$ end and $3^{\prime}$ extension of U8 could disturb processing of the precursor U8 RNAs, but with a preserved function in ribosome biogenesis, acting as hypomorphic functional alleles $(11,14)$. A recently reported vertebrate U8 mutant animal model of LCC-associated U8 variants confirmed that the combination of one severe (null) and one milder (hypomorphic) mutation was responsible for the occurrence of LCC disease (14). However, in our case, the compound heterozygous variants $\mathrm{n} .{ }^{*} 9 \mathrm{C}>\mathrm{T}$ and $\mathrm{n} .3 \mathrm{C}>\mathrm{T}$ in SNORD118 were detected, which both have been predicted as "mild" alleles. It seemed that the combination of these two variants presumably would not result in disease, as homozygous mutations were found in gnomAD (Table 1). It was predicted that such hypomorphic mutant homozygotes would result in the reduction of U8 activity to a level, which is compatible with initially normal development, but insufficient to maintain cellular homeostasis long-term (22). More cases with combination of two "mild" alleles or hypomorphic mutant homozygotes were needed for a better understanding of the molecular pathology of LCC.

Abnormally processed rRNA would impact the construction of ribosomes, affect translation procedure, and might lead to the formation of abnormal cell lumps. It has been hypothesized that diffuse angiomatous dysplastic microangiopathy induces the hypoxia of nearby tissue and ultimately leads to the development of calcifications and cysts. Hemorrhage may also play a critical role in the formation and expansion of 
TABLE 2 | Clinical features of our patient and reported patients with the same disease-causing variant.

\begin{tabular}{|c|c|c|c|c|c|c|c|c|c|c|c|c|c|}
\hline & Our case & $\begin{array}{l}\text { Iwama et al. (12) } \\
\text { (patient 4) }\end{array}$ & $\begin{array}{l}\text { Jenkinson } \\
\text { et al. (11) } \\
\text { (F309) }\end{array}$ & $\begin{array}{l}\text { Jenkinson } \\
\text { et al. (11) } \\
\text { (F1445) }\end{array}$ & $\begin{array}{l}\text { Jenkinson } \\
\text { et al. (11) } \\
\text { (F691) }\end{array}$ & $\begin{array}{l}\text { Jenkinson } \\
\text { et al. (11) } \\
\text { (F819_1) }\end{array}$ & $\begin{array}{l}\text { Jenkinson } \\
\text { et al. (11) } \\
\text { (F819_2) }\end{array}$ & $\begin{array}{l}\text { Jenkinson } \\
\text { et al. (11) } \\
\text { (F1127) }\end{array}$ & $\begin{array}{l}\text { Jenkinson } \\
\text { et al. (11) } \\
\text { (F1172) }\end{array}$ & $\begin{array}{l}\text { Jenkinson } \\
\text { et al. (11) } \\
\text { (F1288) }\end{array}$ & $\begin{array}{l}\text { Jenkinson } \\
\text { et al. (11) } \\
\text { (F551) }\end{array}$ & $\begin{array}{l}\text { Osman et al. } \\
\text { (3) } \\
\text { (patient 2) }\end{array}$ & $\begin{array}{l}\text { Osman et al. } \\
\text { (3) } \\
\text { (patient 5) }\end{array}$ \\
\hline \multirow[t]{2}{*}{ Variant } & n. ${ }^{*} 9 \mathrm{C}>\mathrm{T}$ & n. $3 \mathrm{C}>\mathrm{T}$ & n. $3 \mathrm{C}>\mathrm{T}$ & n. $3 \mathrm{C}>\mathrm{T}$ & n. ${ }^{*} 9 \mathrm{C}>\mathrm{T}$ & n. ${ }^{*} 9 \mathrm{C}>\mathrm{T}$ & n. ${ }^{*} 9 \mathrm{C}>\mathrm{T}$ & n. ${ }^{*} 9 \mathrm{C}>\mathrm{T}$ & n. ${ }^{*} 9 \mathrm{C}>\mathrm{T}$ & n. ${ }^{*} 9 \mathrm{C}>\mathrm{T}$ & n. ${ }^{*} 9 \mathrm{C}>\mathrm{T}$ & n. ${ }^{*} 9 \mathrm{C}>\mathrm{T}$ & n. ${ }^{*} 9 \mathrm{C}>\mathrm{T}$ \\
\hline & n. $3 C>T$ & n. $19 \mathrm{C}>\mathrm{G}$ & n. $131 \mathrm{C}>\mathrm{G}$ & n. $81 G>A$ & n.58A $>G$ & n. ${ }^{*} 1 C>T$ & n. ${ }^{*} 1 C>T$ & n. $100 T>G$ & n. $131 \mathrm{C}>\mathrm{G}$ & n.59T>G & n. $127 \mathrm{C}>\mathrm{G}$ & n.74G $>T$ & n. $131 \mathrm{C}>\mathrm{T}$ \\
\hline Origin & Chinese & Japanese & $\begin{array}{l}\text { North } \\
\text { American }\end{array}$ & British & British & British & British & French & German & $\begin{array}{l}\text { North } \\
\text { American }\end{array}$ & Belgium & French & French \\
\hline Gender & Male & Male & Female & Female & Male & Female & Female & Male & Female & Female & Female & Female & Female \\
\hline $\begin{array}{l}\text { Age at } \\
\text { onset }\end{array}$ & 10 days & N.D. & 2 years & 10 years & $<4$ months & Teens & Teens & $<6$ months & 50 years & 3 years & Infancy & 28 years & 47 years \\
\hline $\begin{array}{l}\text { Current } \\
\text { age }\end{array}$ & 6 years & N.D. & 22 years & 10 years & 4 years & 35 years & 32 years & 2 years & 54 years & 17 years & $\begin{array}{l}\text { Died at age } \\
28 \text { years }\end{array}$ & 38 years & 60 years \\
\hline $\begin{array}{l}\text { Brain } \\
\text { CT/MRI }\end{array}$ & $\begin{array}{l}\text { Focal } \\
\text { calcification in } \\
\text { the right } \\
\text { thalamus. } \\
\text { Bilateral } \\
\text { calcifications } \\
\text { and cysts in } \\
\text { the } \\
\text { periventricular } \\
\text { regions, basal } \\
\text { ganglia, right } \\
\text { thalamus, and } \\
\text { pons. }\end{array}$ & $\begin{array}{l}\text { Brain calcifications, } \\
\text { leukoencephalopathy, } \\
\text { intracranial cyst. }\end{array}$ & $\begin{array}{l}\text { Multiple cysts } \\
\text { and } \\
\text { calcifications. }\end{array}$ & $\begin{array}{l}\text { Multiple cysts } \\
\text { and } \\
\text { calcifications. }\end{array}$ & $\begin{array}{l}\text { Multiple cysts } \\
\text { and } \\
\text { calcifications. }\end{array}$ & $\begin{array}{l}\text { Multiple cysts } \\
\text { and } \\
\text { calcifications. }\end{array}$ & $\begin{array}{l}\text { Multiple cysts } \\
\text { and } \\
\text { calcifications. }\end{array}$ & $\begin{array}{l}\text { Multiple cysts } \\
\text { and } \\
\text { calcifications. }\end{array}$ & $\begin{array}{l}\text { Multiple cysts } \\
\text { and } \\
\text { calcifications. }\end{array}$ & $\begin{array}{l}\text { Multiple cysts } \\
\text { and } \\
\text { calcifications. }\end{array}$ & $\begin{array}{l}\text { Multiple cysts } \\
\text { and } \\
\text { calcifications. }\end{array}$ & $\begin{array}{l}\text { Severe } \\
\text { bilateral and } \\
\text { asymmetric } \\
\text { white-matter } \\
\text { lesions, } \\
\text { extensive } \\
\text { calcifications, } \\
\text { and multiple } \\
\text { cysts with ring } \\
\text { enhancement } \\
\text { of their wall }\end{array}$ & $\begin{array}{l}\text { Multiple cysts } \\
\text { with one } \\
\text { voluminous } \\
\text { cyst located in } \\
\text { the right } \\
\text { cerebellum. } \\
\text { Bilateral and } \\
\text { asymmetric } \\
\text { white-matter } \\
\text { lesions with } \\
\text { many } \\
\text { calcifications. }\end{array}$ \\
\hline $\begin{array}{l}\text { Clinical } \\
\text { features }\end{array}$ & $\begin{array}{l}\text { Seizure, } \\
\text { esotropia, } \\
\text { unsteady } \\
\text { running gait. }\end{array}$ & $\begin{array}{l}\text { Spasticity. (Other } \\
\text { information not } \\
\text { provided.) }\end{array}$ & $\begin{array}{l}\text { Failure to } \\
\text { achieve motor } \\
\text { milestones, } \\
\text { Progressive } \\
\text { spasticity and } \\
\text { dystonia with } \\
\text { complete loss } \\
\text { of speech. }\end{array}$ & $\begin{array}{l}\text { Gait problems, } \\
\text { probably } \\
\text { slowly } \\
\text { progressive } \\
\text { motor } \\
\text { deterioration } \\
\text { with learning } \\
\text { difficulties. }\end{array}$ & $\begin{array}{l}\text { Severe } \\
\text { developmental } \\
\text { delay. }\end{array}$ & $\begin{array}{l}\text { Epileptic } \\
\text { seizures, some } \\
\text { intellectual } \\
\text { delay with } \\
\text { hemiparesis. }\end{array}$ & $\begin{array}{l}\text { Epileptic } \\
\text { seizures, some } \\
\text { intellectual } \\
\text { delay with } \\
\text { hemiparesis. }\end{array}$ & $\begin{array}{l}\text { Moderate } \\
\text { developmental } \\
\text { delay. }\end{array}$ & $\begin{array}{l}\text { Minor degree } \\
\text { al of ataxia and } \\
\text { dysarthria. }\end{array}$ & $\begin{array}{l}\text { Gait } \\
\text { problems, } \\
\text { mainly } \\
\text { unilateral } \\
\text { dystonia/ } \\
\text { spasticity. }\end{array}$ & $\begin{array}{l}\text { Dystonic } \\
\text { quadriplegia, } \\
\text { progressive } \\
\text { neurological } \\
\text { decline. }\end{array}$ & $\begin{array}{l}\text { Progressive } \\
\text { motor deficit } \\
\text { and epileptic } \\
\text { seizures. }\end{array}$ & $\begin{array}{l}\text { Idiopathic } \\
\text { Parkinson's } \\
\text { disease }\end{array}$ \\
\hline
\end{tabular}

N.D., no data. 
cysts. Additionally, abnormal translation-induced pathological myelination, demyelination, and edema in the tissue surrounding cysts may be jointly responsible for the leukoencephalopathy $(5,8,9,23)$. Based on the neuroimaging and histopathological staining of LCC patients, it seems that patients' clinical presentations depend on the location and severity of lesions, including the size of their calcification and cyst, and the severity of their leukoencephalopathy. This disease may break out early or progress rapidly in some patients within several years due to cerebral bleeding, while it may also remain stable in some patients for years due to individual differences (8).

The onset age of LCC patients with a determined genotype had been reported ranging from 3 weeks to 67 years old. The patient who had the earliest onset age was a female reported by Crow et al. (22), presenting seizures at the disease onset. In this manuscript, our case had his first seizure at 10 days after birth, which is earlier than her and all other reported cases until now. In addition, the symptoms of our case were much milder and simpler. The seizures reoccurred for multiple times but have all been controlled. Esotropia and unsteady gait were also developed but later released. At the current stage, the patient was well-developed without additional abnormalities being noticed. Clinical features of our case show that the onset age of LCC was not directly associated with the disease severity. Our case also suggested that for LCC patients, early treatment may result in a better prognosis. Patients that displayed squint during the disease onset were rare, and we report the first patient who had self-limited esotropia. In all reported cases, there have been another three patients harboring the $\mathrm{n} .3 \mathrm{C}>\mathrm{T}$ variant and nine patients harboring the $\mathrm{n} .{ }^{*} 9 \mathrm{C}>\mathrm{T}$ variant, which were identified in our patients. Their brain CTs/MRIs were similar, while the clinical features were not identical. Two patients who harbored $\mathrm{n} .3 \mathrm{C}>\mathrm{T}$ variants had gait problems, while the other two patients had spasticity (Table 2). Patients harboring the n. ${ }^{*} 9 \mathrm{C}>\mathrm{T}$ variants showed seizers (4/10), developmental delay (2/10), intellectual disability (ID, $2 / 10)$, ataxia (1/10), gait problems (1/10), dystonic quadriplegia (1/10), progressive motor deficit (1/10), and idiopathic Parkinson's disease (1/10). We also noticed that for reported patients with $n .{ }^{*} 9 \mathrm{C}>\mathrm{T}$ variation, male patients have a significantly earlier onset age (10 days, 4 months, and 6 months) than female patients (one for infancy, two for teens, and four for 3-50 years) (Table 2) (12). More cases are needed to confirm this conjecture.

Currently, symptomatic treatment is the primary therapy of LCC. Anti-epileptic therapy, corticosteroid therapy, and surgical techniques such as cystic puncture, cystic resection,

\section{REFERENCES}

1. Labrune P, Lacroix C, Goutieres F, de Laveaucoupet J, Chevalier $\mathrm{P}$, Zerah $\mathrm{M}$, et al. Extensive brain calcifications, leukodystrophy, and formation of parenchymal cysts: a new progressive disorder due to diffuse cerebral microangiopathy. Neurology. (1996) 46:1297-301. doi: 10.1212/WNL.46.5.1297

2. Tamura R, Ohira T, Emoto K, Fujiwara H, Horikoshi T, Yoshida K. Leukoencephalopathy, cerebral calcifications, and cysts: a clinical case and cystoventriculoperitoneal shunt may temporarily relieve the symptoms $(2,3,6)$. Fay et al. (24) reported an LCC case who got a marked clinical improvement by biweekly infusions of bevacizumab, an inhibitor of vascular endothelial growth factor, for more than 1 year. This case suggests a promising solution, but efficacy and safety of this treatment still need to be confirmed by further studies.

\section{CONCLUSION}

We report a childhood LCC case with compound heterozygous variants in SNORD118, who had the youngest onset age of LCC with a determined genotype, advancing the range of onset age to 10 days after birth. The triad neuroimaging findings of cerebral calcifications, cysts, and leukoencephalopathy are essential to the diagnosis of LCC. As biopsy is invasive and usually uneasily available, the combined usage of gene assessment and clinical identification should be considered for the diagnosis of LCC.

\section{DATA AVAILABILITY STATEMENT}

The datasets presented in this study can be found in online repositories. The names of the repository/repositories and accession number(s) can be found below: https://www.ncbi.nlm. nih.gov/, PRJNA647511.

\section{ETHICS STATEMENT}

Written informed consent have already been provided to the parents of these patients, and they all agreed to publish the patient's disease information.

\section{AUTHOR CONTRIBUTIONS}

The project was designed by XR and supervised by XR and FF. HJ collected the data, investigated the results, and drafted the manuscript. HW assisted the clinical data curation and patients' care. YH performed the genetic analysis and revised the manuscript. FF also reviewed the manuscript. All authors contributed to the article and approved the submitted version.

\section{ACKNOWLEDGMENTS}

We appreciate the participation of the patients and their parents. We thank MyGenostics Co. and Running Gene Inc. for technology support. involving a long-term follow-up and literature review. J Neurol Sci. (2017) 373:60-5. doi: 10.1016/j.jns.2016.12.014

3. Osman O, Labrune P, Reiner P, Sarov M, Nasser G, Riant F, et al. Leukoencephalopathy with calcifications and cysts (LCC): 5 cases and literature review. Rev Neurol (Paris). (2020) 176:170-9. doi: 10.1016/j.neurol.2019. 06.006

4. Pessoa A. Blood-brain barrier permeability in a patient with Labrune syndrome due to SNORD118 mutations: would this be 
the mechanism for progressive worsening? Eur J Neurol. (2018) 25:e88-90. doi: 10.1111/ene.13671

5. Dey D, Saha S, Dasgupta A. Leukoencephalopathy with cerebral calcifications and cysts in a young adolescent female: a case report. Pak J Radiol. (2018) 28:329-32.

6. Shtaya A, Elmslie F, Crow Y, Hettige S. Leukoencephalopathy, intracranial calcifications, cysts, and SNORD118 mutation (labrune syndrome) with obstructive hydrocephalus. World Neurosurg. (2019) 125:271-2. doi: 10.1016/j.wneu.2019.02.008

7. Brenner C, Del Negro MC, Borigato EM, Miranda RV. Leukoencephalopathy with cerebral calcifications and cysts. Neurology. (2006) 66:E32. doi: 10.1212/01.wnl.0000204297.44936.27

8. Stephani C, Pfeifenbring S, Mohr A, Stadelmann C. Lateonset leukoencephalopathy with cerebral calcifications and cysts: case report and review of the literature. BMC Neurol. (2016) 16:19. doi: 10.1186/s12883-016-0543-1

9. Liu X, Zheng X, Sui Q, Xu W, Zee CS. Leukoencephalopathy with cerebral calcifications and cysts: clinical and pathological features in two adults. Acta Neurol Belg. (2016) 116:47-52. doi: 10.1007/s13760-015-0501-5

10. Wang M, Zhang M, Wu L, Dong Z, Yu S. Leukoencephalopathy with cerebral calcification and cysts: cases report and literature review. J Neurol Sci. (2016) 370:173-9. doi: 10.1016/j.jns.2016.09.048

11. Jenkinson EM, Rodero MP, Kasher PR, Uggenti C, Oojageer A, Goosey LC, et al. Mutations in SNORD118 cause the cerebral microangiopathy leukoencephalopathy with calcifications and cysts. Nat Genet. (2016) 48:1185192. doi: 10.1038/ng.3661

12. Iwama K, Mizuguchi T, Takanashi JI, Shibayama H, Shichiji M, Ito S, et al. Identification of novel SNORD118 mutations in seven patients with leukoencephalopathy with brain calcifications and cysts. Clin Genet. (2017) 92:180-7. doi: 10.1111/cge.12991

13. Wang L, Zuo L, Hu J, Shao H, Lei C, Qi W, et al. Dual LQT1 and HCM phenotypes associated with tetrad heterozygous mutations in KCNQ1, MYH7, MYLK2, and TMEM70 genes in a three-generation Chinese family. Europace. (2016) 18:602-9. doi: 10.1093/europace/euv043

14. Badrock AP, Uggenti C, Wacheul L, Crilly S, Jenkinson EM, Rice GI, et al. Analysis of U8 snoRNA Variants in zebrafish reveals how bi-allelic variants cause leukoencephalopathy with calcifications and cysts. Am J Hum Genet. (2020) 106:694-706. doi: 10.1016/j.ajhg.2020. 04.003

15. Richards S, Aziz N, Bale S, Bick D, Das S, Gastier-Foster J, et al. Standards and guidelines for the interpretation of sequence variants: a joint consensus recommendation of the American College of Medical Genetics and Genomics and the Association for Molecular Pathology. Genet Med. (2015) 17:40524. doi: 10.1038/gim.2015.30
16. Livingston JH, Mayer J, Jenkinson E, Kasher P, Stivaros S, Berger A, et al. Leukoencephalopathy with calcifications and cysts: a purely neurological disorder distinct from coats plus. Neuropediatrics. (2014) 45:17582. doi: 10.1055/s-0033-1364180

17. Mouhadi SE, Chat L, Dafiri R. Leukoencephalopathy with extensive brain calcifications and parenchymal cysts in a child. Eur J Radiol Extra. (2011) 79:e85-8. doi: 10.1016/j.ejrex.2011.04.009

18. Polvi A, Linnankivi T, Kivela T, Herva R, Keating JP, Mäkitie O, et al. Mutations in CTC1, encoding the CTS telomere maintenance complex component 1 , cause cerebroretinal microangiopathy with calcifications and cysts. Am J Hum Genet. (2012) 90:540-9. doi: 10.1016/j.ajhg.2012.02.002

19. Watkins NJ, Bohnsack MT. The box C/D and H/ACA snoRNPs: key players in the modification, processing and the dynamic folding of ribosomal RNA. Wiley Interdiscip Rev RNA. (2012) 3:397-414. doi: 10.1002/wrna.117

20. Kiss T, Fayet E, Jády BE, Richard P, Weber M. Biogenesis and intranuclear trafficking of human box C/D and H/ACA RNPs. Cold Spring Harb Symp Quant Biol. (2006) 71:407-17. doi: 10.1101/sqb.2006.71.025

21. Tomasevic N, Peculis BA. Xenopus LSm proteins bind U8 snoRNA via an internal evolutionarily conserved octamer sequence. Mol Cell Boil. (2002) 22:4101-12. doi: 10.1128/MCB.22.12.4101-4112.2002

22. Crow YJ, Marshall H, Rice GI, Seabra L, Jenkinson EM, Baranano K, et al. Leukoencephalopathy with calcifications and cysts: genetic and phenotypic spectrum. Am J Med Genet A. (2021) 185:15-25. doi: 10.1002/ajmg.a.61907

23. Kaffenberger T, Valko PO, von Meyenburg J, Baráth K, Hewer E, Heppner FL, et al. A case of late onset leukoencephalopathy with cerebral calcifications and cysts in a 59-year-old woman. Eur J Neurol. (2009) 16:27881. doi: 10.1111/j.1468-1331.2008.02392.x

24. Fay AJ, King AA, Shimony JS, Crow YJ, Brunstrom-Hernandez JE. Treatment of leukoencephalopathy with calcifications and cysts with bevacizumab. Pediatr Neurol. (2017) 71:56-9. doi: 10.1016/j.pediatrneurol.2017.03.008

Conflict of Interest: YH was employed by the company Running Gene Inc.

The remaining authors declare that the research was conducted in the absence of any commercial or financial relationships that could be construed as a potential conflict of interest.

Copyright (c) 2021 Jin, Ren, Wu, Hou and Fang. This is an open-access article distributed under the terms of the Creative Commons Attribution License (CC BY). The use, distribution or reproduction in other forums is permitted, provided the original author(s) and the copyright owner(s) are credited and that the original publication in this journal is cited, in accordance with accepted academic practice. No use, distribution or reproduction is permitted which does not comply with these terms. 